\title{
Carrot seeds vigor on plant performance and crop yield
}

\section{Vigor de sementes de cenoura sobre o desempenho das plantas e rendimento da cultura}

\author{
Gisela Hélnia Nunes Chipenete ${ }^{(D)}{ }^{1}$, Denise Cunha Fernandes dos Santos Dias ${ }^{\left(D^{2}\right.}$,

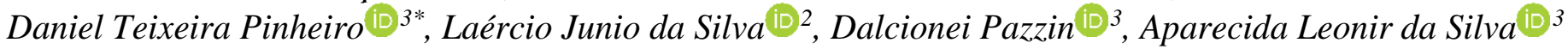

\begin{abstract}
${ }^{1}$ Master in Crop Science at Agronomy Department, Universidade Federal de Viçosa. Av. PH Rolfs, s/n, Viçosa, Minas Gerais, Brazil. ghnchipenete@gmail.com. ${ }^{2}$ Professor at Agronomy Department, Universidade Federal de Viçosa. Av. PH Rolfs, s/n, Viçosa, Minas Gerais, Brazil. dcdias@ufv.br. ; laercio.silva@ufv.br. ${ }^{3} \mathrm{PhD}$ in Crop Science at Agronomy Department, Universidade Federal de Viçosa. Av. PH Rolfs, s/n, Viçosa, Minas Gerais, Brazil. pinheiroagroufv@gmail.com*; dalcionei@hotmail.com ; aparecidaleonir@gmail.com
\end{abstract}

\begin{tabular}{l} 
A R T I G O \\
\hline Recebido: $17 / 07 / 2020$ \\
Aprovado: $26 / 12 / 2020$
\end{tabular}

Key words:

Daucus carota L.

Germination

Productivity

Quality

\section{Palavras-chave:}

Daucus carota L.

Germinação

Produtividade

Qualidade

\begin{abstract}
A B S T R A C T
Rapid emergence and uniform seedling growth are essential attributes in the production of vegetables such as carrots, whose sowing is direct in the field. The experiment was conducted to evaluate the effect of carrot seed vigor on seedling emergence, plant development, and yield. Four seed lots of carrot, cv. Brasília were characterized for their physiological potential by germination and vigor tests. A field experiment was conducted, where the seeds of each lot were sown in in the field to evaluate seedling emergence at 10 and 14 days, the length of the shoot and root at 30, 45 and 60 days after sowing, the crop growth rate, commercial, non-commercial and commercial total roots yield. Seed vigor significantly affected the seedling emergence and development of carrot plants in the field. The less vigorous lot showed lower final emergence than the most vigorous lots and these negative vigor effects extended to the most advanced stages of plant development. Carrot seed vigor affects seedling emergence and plant growth in the field. Vigorous seeds causes greater emergence, plant height and plant dry matter during the vegetative phase. The use of less vigorous seeds causes yield losses of up to $27 \%$.
\end{abstract}

\section{R E S U M O}

A rápida emergência e o crescimento uniforme de plântulas são atributos essenciais na produção de culturas como a cenoura, cuja semeadura é direta no campo. O experimento foi conduzido para avaliar o efeito do vigor de sementes de cenoura na emergência de plântulas, no desenvolvimento e no rendimento da cultura. Quatro lotes de sementes de cenoura, cv. Brasília foram caracterizados por seu potencial fisiológico por testes de germinação e vigor. Foi realizado um experimento de campo, no qual as sementes de cada lote foram semeadas no campo para avaliar a emergência de plântulas aos 10 e 14 dias, o comprimento da parte aérea e da raiz aos 30, 45 e 60 dias após a semeadura, a taxa de crescimento da cultura, raízes comerciais, não comerciais e comerciais totais. $\mathrm{O}$ vigor das sementes afetou significativamente a emergência e o desenvolvimento de mudas de cenoura no campo. $\mathrm{O}$ lote menos vigoroso apresentou menor emergência final do que os lotes mais vigorosos e esses efeitos negativos do vigor se estenderam aos estágios mais avançados do desenvolvimento da planta. $\mathrm{O}$ vigor das sementes de cenoura afeta a emergência de plântulas e o crescimento das plantas no campo. Sementes vigorosas ocasionam maior emergência, altura de planta e matéria seca das plantas durante a fase vegetativa. $\mathrm{O}$ uso de sementes menos vigorosas acarreta perdas de rendimento de até $27 \%$.

\section{INTRODUCTION}

Successful crop production depends on adequate seedling establishment in the field, which is directly related to seed germination and vigor. Seed vigor comprises the sum of seed properties that determine the potential for rapid and uniform seedling emergence under environmental conditions, determining the development, yield, and quality of the harvested product (FINCH-SAVAGE; BASSEL, 2016). Under field conditions, vigorous seeds tend to produce seedlings with higher

\section{Revista Verde}

ISSN 1981-8203

Pombal, Paraíba, Brasil v. 16, n.1, jan.-mar, p.01-08, 2021

doi: $10.18378 /$ rvads.v16i1.8423

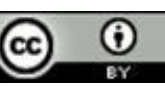


growth rates, uniform emergence, and greater competition and survival. However, low-quality seeds tend to lead to irregular stands, with emergence failures that compromise the quality and yield (NASCIMENTO et al., 2011; LING et al., 2015).

The direct relation between vigorous seeds and satisfactory yield has been reported in crops such as wheat (ABATI et al., 2018), soybean (CAVERZAN et al., 2018) and others. In vegetables, these characteristics are also related (RODO et al., 2003; NASCIMENTO et al., 2011). In squash seeds at different maturity stages, which was observed that seedling vigor is an effective parameter for composing quality control in this species (SILVA et al., 2017). In cucumber, the seed vigor index is directly related to yield (SHARMA et al., 2018). However, in some cases, the effect of seed vigor on plant growth and final yield when there is no reduction in field plant population can be controversial (MONDO et al., 2012).

Carrot (Daucus carota L.) is a vegetable of great importance, with a global production that exceeds 40 million tons per year (SHARMA, 2018). In Brazil, carrot production is around 700,000 tons per year, being a very important activity for the family farm (EMBRAPA, 2020). In this way, it is an extremely important vegetable, since has a good source of nutritional substances such as vitamins, minerals, and dietary fibers (QUE et al., 2019). Moreover, recent studies have shown other benefits of carrots, such as pectin production (JAFARI et al., 2017), carotenoids production (ELLISON et al., 2018), antioxidant properties (DONG et al., 2021), and others. Carrot seeds are small, with few reserves, and are sown directly in the field. According to Nascimento et al. (2011), the vigor in vegetable seeds is important especially for species with these characteristics (small and few reserves), once they are very sensitive to adverse environmental conditions, affecting the uniform seedling establishment and compromising yield and final product quality.

There is not much information about the relation between seed vigor and carrot yield. Therefore, the experiment was conducted to evaluate the effect of carrot seed vigor on seedling emergence, plant development, and final crop yield.

\section{MATERIAL AND METHODS}

The research was conducted in the Agronomy Department at the Universidade Federal de Viçosa, Brazil. Four commercial seed lots of carrot, cultivar "Brasília", were used. Initially, the seeds were evaluated by the following tests to characterize their initial quality:

\section{Moisture content (MC)}

It was determined by the oven method at $105 \pm 3{ }^{\circ} \mathrm{C}$ for 24 hours (BRASIL, 2009). Two replications of $5 \mathrm{~g}$ of seeds were used and the results were expressed as a percentage (\%).

\section{Germination (G)}

The seeds were arranged on two sheets of paper towel, moistened with distilled water (2.5 times the weight of dry paper), in "gerbox" boxes. The boxes were kept in a germinator at $20{ }^{\circ} \mathrm{C}$ and the evaluation was performed at 14 days after sowing (BRASIL, 2009). Four replicates of 50 seeds from each lot were used and the results were expressed as a percentage (\%) of normal seedlings.

\section{First germination count (FGC)}

It was performed together with the germination test, with the evaluation of normal seedlings performed seven days after sowing (BRASIL, 2009).

\section{Seedling emergence (SE) and seedling emergence speed index (ESI)}

It was carried out in a greenhouse with four replications of 50 seeds sowed in polystyrene trays containing moistened sand up to $2 / 3$ of the retention capacity. Daily evaluations were made of the number of emerged seedlings with a size equal to or greater than $1.0 \mathrm{~cm}$ until the counts stabilization. The results were expressed as a percentage (\%) of normal seedlings. For the emergence speed index (ESI), the Equation 1 proposed by Maguire (1962) was used:

$$
\mathrm{ESI}=\frac{\mathrm{E}_{1}}{\mathrm{~N}_{1}}+\frac{\mathrm{E}_{2}}{\mathrm{~N}_{2}}+\cdots+\frac{\mathrm{E}_{\mathrm{n}}}{\mathrm{N}_{\mathrm{n}}}
$$

Where: ESI $=$ Emergence speed index $\left(\right.$ seedlings.day $\left.{ }^{-1}\right) ; \mathrm{E}_{1}, \mathrm{E}_{2}$, $E_{n}=$ Number of normal seedlings computed in the first count, in the second count and last count; $\mathrm{N}_{1}, \mathrm{~N}_{2}, \mathrm{~N}_{\mathrm{n}}=$ Number of days after sowing from the first count to the second count and the last count.

\section{Controlled Deterioration (CD)}

Initially, the moisture content of the seeds was adjusted to $24 \%$ by the moist atmosphere method at $20{ }^{\circ} \mathrm{C}$. The moisture content of the seeds was monitored by successive weighing at one-hour intervals until the desired values were obtained. The seeds were placed in aluminized paper bags, which were hermetically sealed and kept in a refrigerator at $10{ }^{\circ} \mathrm{C}$ for $24 \mathrm{~h}$. After this period, they were kept in a water bath at $45{ }^{\circ} \mathrm{C}$ for 24 h (KRZYZANOWSKI; MARCOS-FILHO, 2020). Then the seeds were placed to germinate as described for the germination test (BRASIL, 2009). Four replicates of 50 seeds from each lot were used and the results were expressed as the percentage of normal seedlings obtained seven days after sowing.

\section{Germination at sub $\left(\mathrm{G15}^{\circ}\right)$ and supra optimum $\left(\mathrm{G30}^{\circ}\right)$ temperatures}

Four replications of 50 seeds were placed to germinate according to the germination test, but at temperatures of $30{ }^{\circ} \mathrm{C}$ (supra-optimum) and $15{ }^{\circ} \mathrm{C}$ (sub-optimal) in a BOD incubator. The results were expressed as a percentage (\%) of normal seedlings obtained at seven days after sowing for supra-optimal temperature and at 10 days for sub-optimal temperature.

After the initial characterization of the lots, a field experiment was conducted. Two rows of $20 \mathrm{~m}$ long and $1 \mathrm{~m}$ wide each were prepared, with four blocks of $5 \mathrm{~m}$ each. Four replicates of 100 seeds from each lot were sown in longitudinal grooves 1 $\mathrm{m}$ long and $2 \mathrm{~cm}$ deep, $0.20 \mathrm{~m}$ apart. The lateral grooves were considered as borders and the useful area only the two central grooves (MATOS et al., 2011). The soil chemical analysis was performed (Table 1). Before sowing, fertilization with 40, 180, and $60 \mathrm{~kg} \mathrm{ha}^{-1}$ of $\mathrm{N}, \mathrm{P}_{2} \mathrm{O}_{5}$, and $\mathrm{K}_{2} \mathrm{O}$ respectively was performed, defined on the basis of soil analysis results and fertilizer recommendations for carrot cultivation (AQUINO et al., 2016). 
Table 1. Chemcical analysis of the soil.

\begin{tabular}{|c|c|c|c|c|c|}
\hline $\mathrm{pH}$ & $\mathrm{P}$ & $\mathrm{K}$ & $\mathrm{Ca}^{2+}$ & $\mathrm{Mg}^{2+}$ & $\mathrm{Al}^{3+}$ \\
\hline $\mathrm{H}_{2} \mathrm{O}$ & \multicolumn{2}{|c|}{ mg.dm ${ }^{3-1}$} & \multicolumn{3}{|c|}{$\mathrm{cmol} . \mathrm{dm}^{3-1}$} \\
\hline 6.3 & 58.3 & 220 & 2.7 & 1.0 & 0 \\
\hline $\mathrm{H}+\mathrm{AL}$ & SB & CTC (t) & cmol.dm ${ }^{3-1}$ & V & $\mathrm{m}$ \\
\hline 3.0 & 4.2 & 4.2 & 7.2 & 59 & 0 \\
\hline $\begin{array}{l}\mathrm{H} \text { in water, } \\
\mathrm{Al} \text { - Extrac } \\
\mathrm{H} 7,0 . \mathrm{SB} \\
\text { apacity. CT }\end{array}$ & $\begin{array}{l}\mathrm{l} \text { and } \\
\mathrm{KCl} \\
\mathrm{um} \text { of } \\
\mathrm{T} \text { ) - Ca } \\
\text { saturat }\end{array}$ & $\begin{array}{l}\mathrm{Cl} \text { - Relatio } \\
\text { mol/L. H } \\
\text { xchangeabl } \\
\text { on exchang } \\
\mathrm{n} \text { index. }\end{array}$ & $\begin{array}{l}: 2,5 . \mathrm{P}-\mathrm{K} \\
\mathrm{l}-\mathrm{Calciun} \\
\text { ases CTC } \\
\text { apacity. pH }\end{array}$ & $\begin{array}{l}\text { lich ex } \\
\text { ate ext } \\
\text { ffective } \\
I=\text { Bas }\end{array}$ & $\begin{array}{l}\text { r } 1 . \mathrm{Ca} \\
0.5 \mathrm{~m} \\
\text { on excl } \\
\text { ation i }\end{array}$ \\
\hline
\end{tabular}

In the first two weeks, two irrigations were performed per day, lasting two hours each, keeping the surface of the bed always moist. From then on, only daily irrigation lasting $2 \mathrm{~h}$ was performed. The crop treatments were performed whenever necessary. Topdressing fertilization was performed at 28 and 45 days after sowing, using $60 \mathrm{~kg} \mathrm{ha}^{-1}$ of $\mathrm{N}$ and $\mathrm{K}$, respectively. At 28 days after sowing, thinning was done leaving a spacing of about $5 \mathrm{~cm}$ between plants. One of the rows was used to evaluate seedling emergence in the field and the other to evaluate vegetative development and final crop production. In this, the harvest was performed at 90 days after sowing.

The maximum, average and minimum temperatures and relative humidity recorded during the experimental period, as well as monthly cumulative rainfall are shown in Figure 1.

Figure 1. Minimum (Min.), average (Aver.), and maximum (Max.) temperatures $\left({ }^{\circ} \mathrm{C}\right)$; relative air humidity $(\%)(\mathrm{A})$ and cumulative rainfall (B) during carrot development in the field

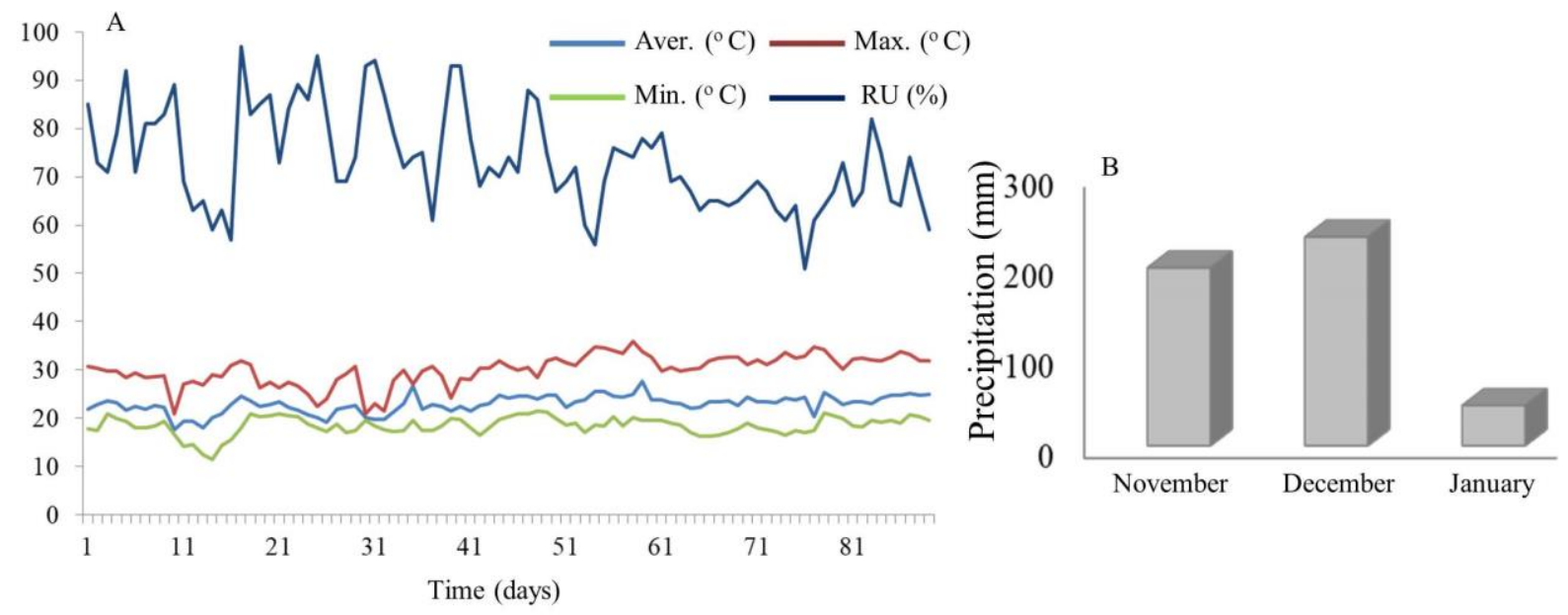

\section{Field seedling emergence}

Field seedling emergence was represented by percentage of normal seedlings emerged (at least $1.0 \mathrm{~cm}$ height) at 10 and 14 days after sowing.

For evaluation of vegetative development, samples of 8 plants per replication were taken at 30, 45 and 60 days after sowing, making the following evaluations:

\section{Plant height and root length}

The height of each plant was measured from the base to the top and the length of the root was measured with the aid of a ruler. The results were expressed in $\mathrm{cm}$ plant $^{-1}$ (KRZYNANOWSKI et al., 2020).

\section{Shoot and root dry matter}

Plants were separated into root and shoots, placed separately in paper bags and kept in a oven with regulated air circulation at $70{ }^{\circ} \mathrm{C}$ until they reached constant weight. The dried material was weighed on a precision scale and the results were expressed in g plant $^{-1}$ (KRZYNANOWSKI et al., 2020).

\section{Shoot and root growth rate}

With shoot and root dry matter values, shoot and root growth rate (GR) (Equation 2) were determined, according to Kolchinski et al. (2006).

$$
\mathrm{GR}=\frac{\left(\mathrm{DM}_{2}-\mathrm{DM}_{1}\right)}{\left(\mathrm{T}_{2}-\mathrm{T}_{1}\right)}
$$

Where: $\mathrm{DM}_{1}$ : Value of dry mass obtained on the first day of the period to be considered $\left(\mathrm{T}_{1}\right) ; \mathrm{DM}_{2}$ : Value of dry mass obtained on the last day of the period to be considered $\left(\mathrm{T}_{2}\right)$; GR values are given in g.plant ${ }^{-1} \cdot$ day $^{-1}$.

\section{Evaluation of crop production and yield}

Harvesting was performed by collecting plants from all useful areas $\left(25 \mathrm{~m}^{2}\right.$ per block). The roots were separated from the shoots and weighed to determine the total roots yield in $\mathrm{kg}$. Then they were classified into: commercial (length greater than $12 \mathrm{~cm}$ ) and non-commercial (length less than $12 \mathrm{~cm}$ and / or roots with defects such as purple / green shoulder, bifurcation and crack) (CEAGESP, 2015).

\section{Statistical analysis and experimental design}

The seed quality tests were conducted in a completely randomized design with four replications. The data were submitted to analysis of variance and the means obtained for each lot were compared by Tukey test at $5 \%$ probability.

The field experiment was conducted in a completely randomized block design with four replications. The data obtained for each variable were submitted to analysis of variance. The means obtained for each lot were compared by the Tukey 
test at $5 \%$ probability. Pearson correlation analysis was performed at 1 and $5 \%$ probability. The R software was used in all statistical analyses (R Core Team, 2020).

\section{RESULTS AND DISCUSSION}

The seed moisture content was similar for all analyzed lots, being around $7 \%$. This value is adequate for the packaging of vegetable seeds stored in hermetically sealed aluminum containers. The germination of the lot 3 was inferior to the others, which did not differ significantly from each other. Similar results were obtained in the seedling emergence, emergence speed index, controlled deterioration, and germination at supra-optimal temperature (Table 2).

Table 2. Seed moisture content (MC), germination (G), first germination count (FGC), seedling emergence (SE), emergence speed index (ESI), controlled deterioration (CD), temperature germination sub $\left(\mathrm{G}^{\circ} 5^{\circ}\right)$ and supra-optimal $\left(\mathrm{G} 30^{\circ}\right)$ obtained for the four seed lots of carrot.

\begin{tabular}{|c|c|c|c|c|c|c|c|c|}
\hline \multirow{2}{*}{ Lots } & $\mathrm{MC}$ & $G$ & FGC & SE & \multirow[t]{2}{*}{ ESI } & $\mathrm{CD}$ & $\mathrm{G}^{\prime} 5^{\circ}$ & $\mathrm{G} 30^{\circ}$ \\
\hline & & & $\%)$ & & & \multicolumn{3}{|c|}{$(\%)$} \\
\hline 1 & 7.2 & $83.5 \mathrm{a}$ & $77.0 \mathrm{a}$ & $69 \mathrm{a}$ & $18 \mathrm{a}$ & $51 \mathrm{a}$ & $77.0 \mathrm{a}$ & $76.5 \mathrm{a}$ \\
\hline 2 & 7.7 & $81.5 \mathrm{a}$ & $72.5 \mathrm{ab}$ & $67 \mathrm{a}$ & $20 a$ & $51 \mathrm{a}$ & $79.5 \mathrm{ab}$ & $71.0 \mathrm{a}$ \\
\hline 3 & 7.2 & $68.7 \mathrm{~b}$ & $62.5 \mathrm{~b}$ & $47 \mathrm{~b}$ & $12 \mathrm{~b}$ & $39 \mathrm{~b}$ & $64.0 \mathrm{~b}$ & $53.0 \mathrm{~b}$ \\
\hline 4 & 7.3 & $82.5 \mathrm{a}$ & $74.0 \mathrm{ab}$ & $68 \mathrm{a}$ & $20 \mathrm{a}$ & $53 \mathrm{a}$ & $75.5 \mathrm{ab}$ & $72.0 \mathrm{a}$ \\
\hline CV (\%) & - & 6.24 & 8.01 & 9.97 & 13.34 & 10.91 & 8.64 & 7.23 \\
\hline
\end{tabular}

Means followed by the same letter in the column do not differ from each other by the Tukey test at 5\% probability. CV: Coefficient of variation

In general, all of these tests are important for assessing seed performance under adverse conditions, defining seed vigor (FINCH-SAVAGE; BASSEL, 2016). In this context, the first germination count and sub-optimal temperature germination tests allowed to classify the seed lots into three vigor levels, being lot 1 as the most vigorous, lot 3 the less vigorous, and lots 2 and
4 as intermediate. In all tests performed, we found worse performance for seed lot 3 compared to the others (Table 2).

Through the correlation analysis between the physiological quality evaluation and the emergence of the field, it is observed that the first germination count and sub-optimal germination temperature were significantly correlated with the seedling emergence at 10 and 14 days (Table 3 ).

Table 3. Pearson correlation coefficients obtained between germination (G), first germination count (FGC), seedling emergence (SE), controlled deterioration (CD), emergence speed index (ESI), germination at optimum sub $\left(\mathrm{G}^{\circ} 5^{\circ}\right)$ and supra $\left(\mathrm{G} 30^{\circ}\right)$ temperature and emergence results at 10 (EM10) and 14 (EM14) days for four carrot lots.

\begin{tabular}{|c|c|c|c|c|c|c|c|c|c|}
\hline & $\mathrm{G}$ & FGC & SE & $\mathrm{CD}$ & ESI & $\mathrm{G}^{\circ} 5^{\circ}$ & $\mathrm{G}^{\circ} 0^{\circ}$ & EM10 & EM14 \\
\hline $\mathrm{G}$ & & $0.629 * *$ & $0.827 * *$ & $0.564 *$ & $0.729 * *$ & $0.529 *$ & $0.724 * *$ & 0.350 & 0.235 \\
\hline FGC & & & $0.602 *$ & $0.712 * *$ & $0.577 *$ & $0.777^{* *}$ & $0.628^{*}$ & $0.644 *$ & $0.748^{* *}$ \\
\hline SE & & & & $0.509 *$ & $0.895 * *$ & $0.689 * *$ & $0.776 * *$ & 0.457 & 0.284 \\
\hline $\mathrm{CD}$ & & & & & $0.528 *$ & $0.569^{*}$ & $0.659 * *$ & 0.250 & $0.578 *$ \\
\hline ESI & & & & & & $0.523^{*}$ & $0.702 * *$ & 0.270 & 0.276 \\
\hline G15 ${ }^{\circ}$ & & & & & & & $0.598^{*}$ & $0.637 *$ & $0.606^{*}$ \\
\hline $\mathrm{G} 30^{\circ}$ & & & & & & & & 0.472 & $0.500 *$ \\
\hline EM10 & & & & & & & & & $0.649 *$ \\
\hline EM14 & & & & & & & & & \\
\hline
\end{tabular}

*;**: Significant correlation at 5 and $1 \%$ probability, respectively.

It was also observed that there was a significant correlation among the data obtained from controlled deterioration, germination at supra-optimal temperature, and emergence at 14 days (Table 3). These results indicate an association between laboratory vigor test results and the emergence of carrot seedlings in the field. Thus, the first germination count, controlled deterioration, and germination tests at the sub and supra-optimal temperatures provided an estimate of field seed performance. Among these tests, the first germination count test is recommended to evaluate the physiological quality of carrot seeds due to its simplicity of conduction and efficiency in ranking lots.

The germination at sub or supra-optimal temperatures has been successfully used to classify seed lots of carrot (SINGH et al., 2014), cucumber (BALABUSTA et al., 2016), and melon (PINHEIRO et al., 2017). As observed, the germination at suboptimal temperature was directly related to the carrot emergence. It's also related that temperatures above $30^{\circ} \mathrm{C}$ caused decreases in seed germination of both "Brasília" and "Alvorada" cultivars. Dias et al. (2015) observed that the germination of cultivar "Brasília" was reduced by the temperature of $35^{\circ} \mathrm{C}$. In general, these effects can be related to many cellular alterations such as hormonal imbalance, genetic alterations, and others, the reduce seed germination and vigor (WANG et al., 2018).

Lots 1 and 3 presented higher and lower emergence in the field at 10 (Figure 2A) and 14 days (Figure 2B) after sowing, respectively. 
Figure 2. Field seedling emergence $(\%)$ of four carrot seed lots at 10 (A) and 14 (B) days after sowing

10 days

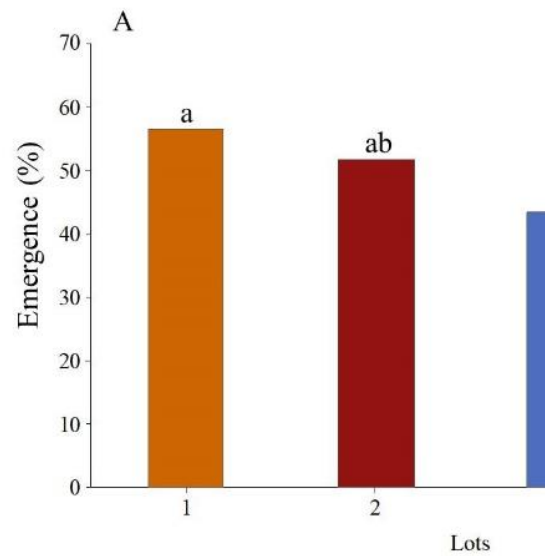

14 days

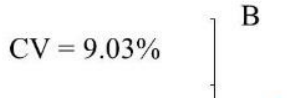

$\mathrm{CV}=10.40 \%$

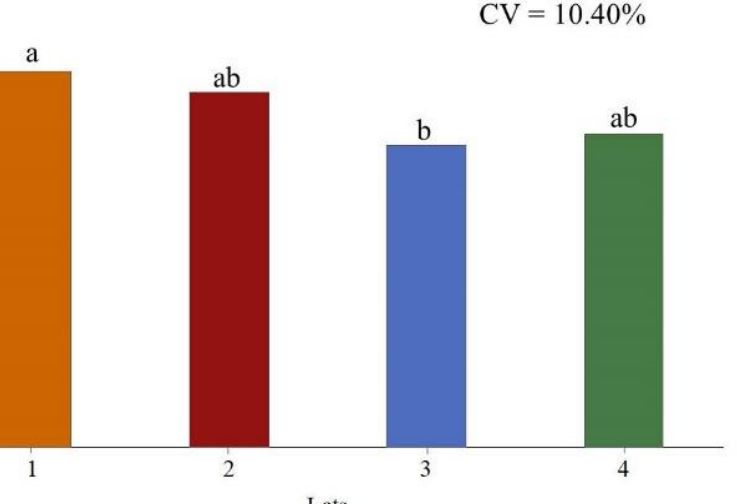

Lots

Means followed by the same letters do not differ among lots within each period by the Tukey test at 5\% probability. CV: Coefficient of Variation

The poor performance of lot 3 (less vigor) was also observed in laboratory tests for physiological potential evaluation (Table 2). It's probably related to the lower amount of energetic reserves in these seeds, which is important for embryonic nutrition and seedling development (NONOGAKI et al., 2020).

The field seedling emergence was less than $60 \%$ for all analyzed lots (Figure 2). Singh et al. (2014) evaluated the emergence of eight commercial carrot lots and observed field emergence of between 33.2 to $56.5 \%$, similar results to those observed. Marchi and Cicero (2017) evaluated seven carrot lots and observed that seedling emergence was directly related to vigor, reinforcing the importance of this test.

It was observed that there was no significant difference between plots regarding plant height at 30 days after sowing and root length at 30, 45, and 60 days. However, at 45 and 60 days, there was a lower height of plants from lot 3 compared to the other lots (Figure 3A).

Figure 3. Plant height (A), root length (B), shoot (C), and root (D) dry matter at 30, 45, and 60 days after sowing of four carrot seed lots.
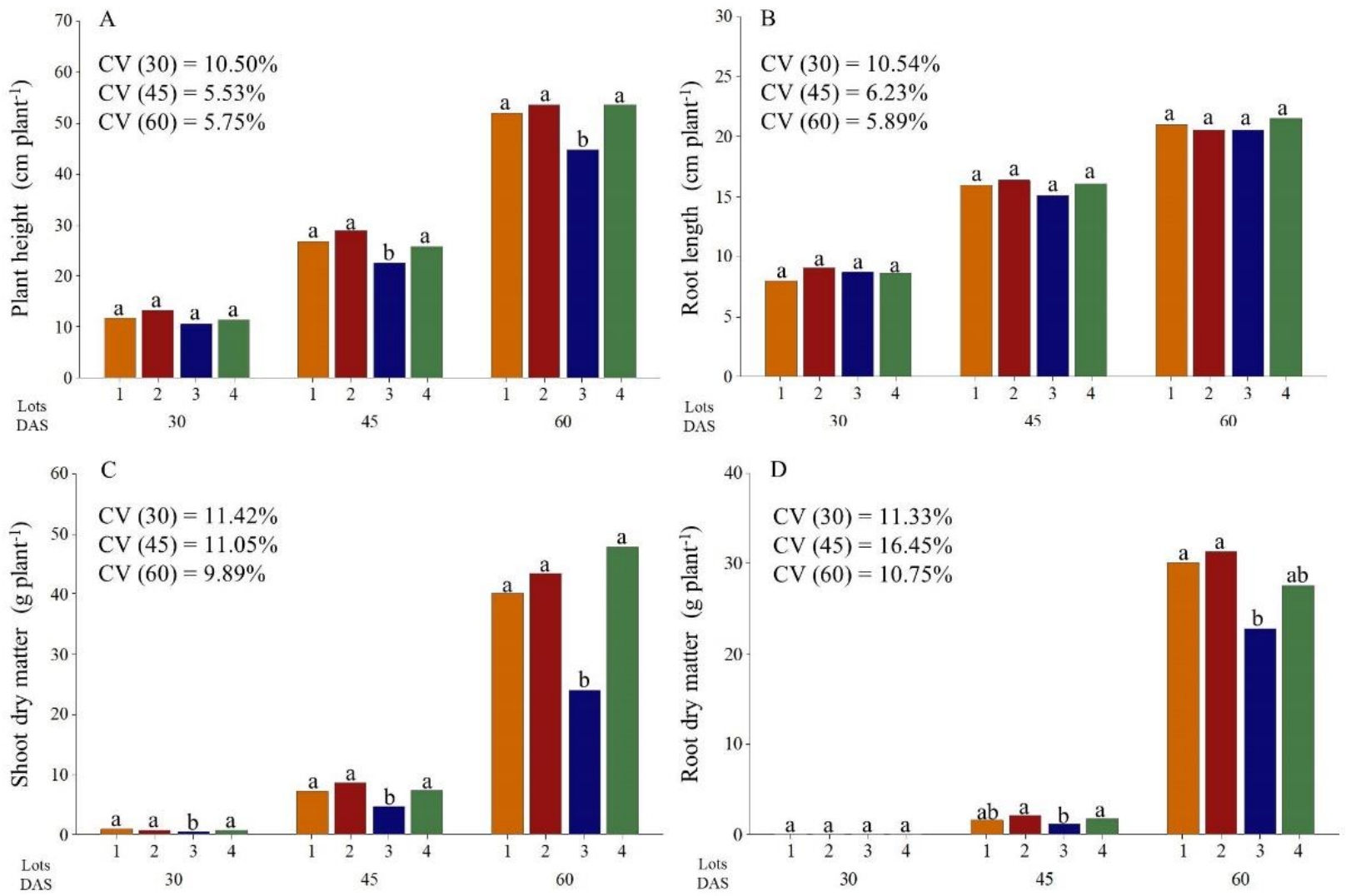

Means followed by the same letters do not differ among lots within each period by the Tukey test at 5\% probability. CV: Coefficient of Variation 
Lot 3 showed lower physiological potential through vigor tests (Table 2). Therefore, it is confirmed that the less vigorous seeds originated in smaller plants (Figure 3A). The shoot and root dry matter presented similar results at 45 and 60 days (Figure 3 $\mathrm{C}$ and $4 \mathrm{C}$ ).

The effects of vigor on plant shoot height were observed later, at 45 and 60 days after sowing (Figure 3 A). This fact is understandable due in longer cycle crops, the effect of genotype $\mathrm{x}$ environment interaction assumes greater relevance and may nullify the effects of seed vigor (TEKRONY; EGLI, 1991; NASCIMENTO et al., 2011). Moreover, vigorous seeds allowed plants with higher initial growth, but these effects did not persist until later evaluation periods (MONDO et al., 2012).

According to Finch-Savage and Bassel (2016), temperature is one of the main factors that affect the emergence and plant growth. These authors also mention that solar radiation with water content can cause the soil surface to heat to the point of affecting the microbial activity and reducing seed vigor. In this context, no drastic changes in temperatures were observed, with maximum values of approximately $30^{\circ} \mathrm{C}$ and average around 25 ${ }^{\circ} \mathrm{C}$ (Figure 1A). Precipitation data during the experimental period are shown in Figure 1B, and it should be noted that the experiment was conducted under irrigation, maintaining the availability of water in the soil at an appropriate level for plant development until harvest. Thus, it was avoided that environmental factors could negatively affect plant development so that the observed results could be due to seed vigor.

Considering the field development, lot 3 presented the lowest shoot and root growth rate, with differences of up to 50\% when compared to the highest vigor (lots 1 and 4) (Figure 4).

Figure 4. Shoot (A) and root (B) growth rate of plants at 30, 45, and 60 days after sowing (DAS) of four carrot seed lots
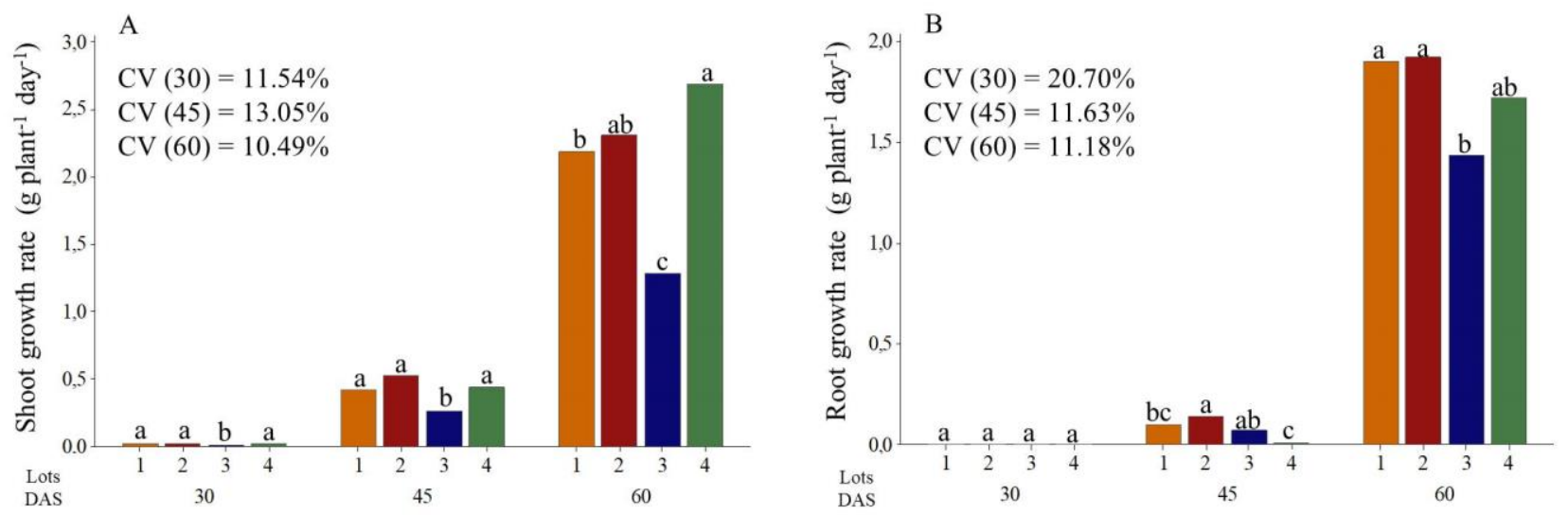

Means followed by the same letters do not differ among lots within each period by the Tukey test at 5\% probability. CV: Coefficient of Variation

Considering the shoot growth (Figure 4A), lot 3 was inferior to the others in all seasons. For the root growth (Figure 4B), this lot had less performance than the others only at 60 days. The vigor effects on plant growth have been observed in crops such as pea (STOLÁRIK et al., 2015), and wheat (ZAHORANOVÁ et al., 2016), wherein general, plants originating from lower vigor seeds had lower growth rate. The results observed for dry matter and growth rate are expected since more deteriorated seeds will have greater degradation of energy reserves such as lipids, proteins, and soluble sugars that are directed to the embryonic axis for seedling formation (OLIVEIRA et al., 2017).

As observed, seed vigor affected carrot field performance. For short-cycle vegetables, such as carrots, the effects of seed vigor can directly affect plant growth and dry matter accumulation in the field. TeKrony and Egli (1991) attest that seed vigor has the most significant effect on the yield of crops whose commercial product is harvest in the vegetative phase or in the early reproductive phase. These authors point out that the effects of seed vigor at the final stand may be especially critical for crops that require adequate spatial distribution of plants to maximize yield, and delaying or decreasing seedling emergence may reduce yield at harvest.
Considering the four analyzed lots, no significant differences were observed in commercial/non-commercial root yield, and in the total carrot root yield (Table 4).

Table 4. Commercial, non-commercial and total carrot root yield and average productivity at 90 days after sowing of four seed lots.

\begin{tabular}{ccccc}
\hline \multirow{2}{*}{ Lots } & \multicolumn{3}{c}{ Roots yield $(\mathrm{kg})$} & Yield \\
\cline { 2 - 5 } & Commercial & $\begin{array}{c}\text { Non- } \\
\text { commercial }\end{array}$ & Total & $\begin{array}{c}\text { Productivity } \\
\left(\mathrm{t} \mathrm{ha}^{-1}\right)\end{array}$ \\
\hline 1 & $2.72 \mathrm{a}$ & $0.866 \mathrm{a}$ & $3.59 \mathrm{a}$ & $68.0 \mathrm{a}$ \\
2 & $2.94 \mathrm{a}$ & $0.5999 \mathrm{a}$ & $3.54 \mathrm{a}$ & $73.6 \mathrm{a}$ \\
3 & $2.15 \mathrm{a}$ & $0.835 \mathrm{a}$ & $2.99 \mathrm{a}$ & $53.9 \mathrm{a}$ \\
4 & $2.68 \mathrm{a}$ & $0.780 \mathrm{a}$ & $3.46 \mathrm{a}$ & $67.0 \mathrm{a}$ \\
\hline $\mathrm{CV}(\%)$ & 15.92 & 19.59 & 14.34 & 15.92 \\
\hline
\end{tabular}

Means followed by the same letter in the column do not differ by the Tukey test at $5 \%$ probability. CV: Coefficient of Variation

Moreover, the yield of $53.9 \mathrm{t} \mathrm{ha}^{-1}$ obtained for lot 3 was $27 \%$ lower than the highest yield obtained $\left(73.6 \mathrm{t} \mathrm{ha}^{-1}\right)$, which in economic terms is not negligible. In current studies, the direct relation between seed vigor and field yield is confirmed in different crops. In wheat, the seed vigor was associated with the higher seedling establishment, growth, and development of plants at the initial phenological stages (ABATI et al., 2018). 
These authors cite the possibly contributed to the increased light use efficiency, and greater interception of the photosynthetically active radiation by the canopy, influencing the grain yield. In soybean, plants originated from the high-vigor seeds presented more efficiency on nitrogen fixation (CAVERZAN et al., 2018). Therefore, these and other effects may have influenced the results observed in the carrot.

In the present study, it was observed that the use of low vigor seed can negatively affect the final yield of carrot roots, causing losses of up to $27 \%$ in the average yield in relation to the use of higher vigor seeds.

According to Nascimento et al. (2011), the effect of seed vigor on seedling emergence and initial stand are relevant and may interfere with plant development and uniformity of the harvested product, making it difficult to standardize. These authors consider that seed vigor is important for crops whose commercial product is the shoot of the plant. In this context are leafy of vegetables, or certain organs obtained from the plant that was harvested, usually an underground structure like carrot, beets, onions, radishes, and turnips.

It is important to emphasize that failures in the final stand are crucial for the production and the final quality of the harvested product. Proper spacing between carrot plants in the field is critical for proper root growth, as stand failures can favor thicker roots, which are not well accepted in many consumer markets.

\section{CONCLUSIONS}

Carrot seed vigor affects seedling emergence and plant growth in the field. Vigorous seeds cause higher emergence, plant height, and dry matter during the vegetative phase. The use of less vigorous seeds causes yield losses of up to $27 \%$.

\section{ACKNOWLEDGMENTS}

The authors are grateful to Claudio Chipenete (for assisting the statistical analysis) and the Universidade Federal de Viçosa (UFV). This study was funded in part by the Coordenação de Aperfeiçoamento de Pessoal de Nível Superior - Brasil (CAPES) - (Funding Code: 001), Conselho Nacional de Desenvolvimento Científico e Tecnológico (CNPq), and Fundação de Amparo à Pesquisa do Estado de Minas Gerais (FAPEMIG).

\section{REFERÊNCIAS}

ABATI, J.; BRZEZINSKI, C. R.; ZUCARELI, C.; FOLONI, J. S. S.; HENNING, F. A. Growth and yield of wheat in response to seed vigor and sowing densities. Revista Caatinga, v.31, n.4, p.891-899, 2018. 10.1590/1983-21252018v31n411rc.

AOSA. Seed vigor testing handbook. Contribution no. 32. IthacaNY: Association of Official Seed Analysts. 2009.

AQUINO, L. A.; DEZORDI, L. R.; CLEMENTE, J. M. Nutrição, calagem e adubação. In: NICK, C.; BORÉM, A. (Org.). Cenoura: do plantio a colheita. Viçosa-MG: Editora UFV, 2016. v.1, p.42-65.
BALABUSTA, M.; SZAFRAŃSKA, K.; POSMYK, M. M. Exogenous melatonin improves antioxidant defense in cucumber seeds (Cucumis sativus L.) germinated under chilling stress. Frontiers in Plant Science, v.7, p.575, 2016. 10.3389/fpls.2016.00575.

BRASIL. Regras para Análise de Sementes. Brasília: Ministério da Agricultura, Pecuária e Abastecimento. 2009. 395p. Available in:

$<$ https://www.abrates.org.br/files/regras_analise_de_sementes.p df. $>$

CAVERZAN, A.; GIACOMIN, R.; MÜLLER, M.; BIAZUS, C.; LÂNGARO, N. C.; CHAVARRIA, G. How does seed vigor affect soybean yield components?. Agronomy Journal, v.110, n.4, p.1318-1327, 2018. 10.2134/agronj2017.11.0670.

CEAGESP. Normas de classificação de cenoura (Daucus carota L.). Brasília, DF. 2015. 5p.

DIAS, M. A.; LOPES, J. C.; GUIMARÃES, G. A. M.; DE SOUZA NETO, J. D.; DE OLIVEIRA BERNARDES, C. Carrot seed germination in different conditions of salinity and temperature. Idesia, v.33, n.4, p.41-46, 2015.

ELLISON, S. L.; LUBY, C. H.; CORAK, K. E.; COE, K. M.; SENALIK, D.; IORIZZO, M.; GOLDMAN, I. L.; SIMON, P. W.; DAWSON, J. C. (2018). Carotenoid presence is associated with the or gene in domesticated carrot. Genetics, v.210, n.4, p.1497-1508, 2018. 10.1534/genetics.118.301299

EMBRAPA. The history of the carrot. Brasília, DF: EMBRAPA. 2020. Available in: <https://www.embrapa.br/busca-denoticias/-/noticia/49845405/a-historia-da-cenoura> .

FINCH-SAVAGE, W. E.; BASSEL. G. W. Seed vigour and crop establishment: Extending performance beyond adaptation. Journal of Experimental Botany, v.67, n.3, p.567-591. 2016. 10.1093/jxb/erv490.

JAFARI, F.; KHODAIYAN, F.; KIANI, H.; HOSSEINI, S. S. Pectin from carrot pomace: Optimization of extraction and physicochemical properties. Carbohydrate polymers, v.157, n.2017, p.1315-1322, 2017. 10.1016/j.carbpol.2016.11.013

KOLCHINSKI, E. M.; SCHUCH, L. O. B.; PESKE, S. T. Early growth of soybean plants in relation to seeds vigor. Revista Brasileira de Agrociência, v.12, n.2, p.163-166, 2006. $\underline{10.18539 / \text { cast.v12i } 2.4513}$

KRZYZANOWSKI, F. C.; FRANÇA-NETO, J. B.; GOMESJUNIOR, F. G.; NAKAGAWA, J. Vigor tests based in seedling performance. In Krzyzanowski, F. C.; Vieira, R. D.; FrançaNeto, J. B.; Marcos-Filho, J. (Org). Seed vigor: concepts and tests. Londrina-PR: ABRATES, 2020. p. 77-138.

KRZYZANOWSKI, F. C.; MARCOS-FILHO, J. Controled deterioration. In Krzyzanowski, F. C.; Vieira, R. D.; FrançaNeto, J. B.; Marcos-Filho, J. (Org). Seed vigor: concepts and 
tests. Londrina-PR: ABRATES, 2020. p. 245-275.

LING, L.; JIAFENG, J.; JIANGANG, L.; MINCHONG, S.; XIN, H.; HANLIANG, S.; YUANHUA, D. Effects of cold plasma treatment on seed germination and seedling growth of soybean. Scientific Reports, v.4, n.2014, p.5859. 2014. $\underline{10.1038 / \text { srep05859 }}$

MAGUIRE, J. D. Speed of germination - Aid in selection and evaluation for seedling emergence and vigor. Crop Science, v.2, n.2, p.176, 1962. 10.2135/cropsci1962.0011183X000200020033x.

MARCHI, J. L. D.; CICERO, S. M. Use of the software Seed Vigor Imaging System (SVIS®) for assessing vigor of carrot seeds. Scientia Agricola, v.74, n.6, p.469-473, 2017. $\underline{10.1590 / 1678-992 x-2016-0220 .}$.

MATOS, F. A. C.; LOPES, H. R. D.; DIAS, R. L.; ALVES, R. T. Carrot: Learn how to grow vegetables to sow good business. Brasília: DF: SEBRAE, 2011. 28 p.

MONDO, V. H. V.; CICERO, S. M.; NETO, D. D.; PUPIM, T. L.; DIAS, M. A. N. Maize seed vigor and plant performance. Revista Brasileira de Sementes, v.34, n.1, p.143-155, 2012.

NASCIMENTO, W. M.; DIAS, D. C. F. S.; SILVA, P. P. Seed quality and stablishment of vegetable plants in the field. In Nascimento, W. M. (Org.). Seed technology and production of vegetables. Brasília-DF: Embrapa Hortaliças, 2011. p.79-106.

NONOGAKI, H.; NISHIYAMA, E.; OHSHIMA, K.; NONOGAKI, M. Ancient Memories of Seeds: ABA-Dependent Growth Arrest and Reserve Accumulation. Trends in Genetics, v.36, n.7, p.464-473, 2020. 10.1016/j.tig.2020.04.009.

OLIVEIRA, D. F. A.; MELO, S. M. B.; AVELINO, A. P.; MACÊDO, C. E. C.; PACHECO, M. V.; VOIGT, E. L. The deterioration of Moringa oleifera Lam. seeds in the course of storage involves reserve degradation. Acta Physiologiae Plantarum, v.39, n.12, p.269, 2017. 10.1007/s11738-017-25729.

PINHEIRO, D. T.; DIAS, D. C. F. S.; ARAÚJO, J. O. Germination of melon seeds under water and thermal stress. Journal of Seed Science, v.39, n.4, p.440-447, 2017. 10.1590/2317-1545v39n4188530.

QUE, F.; HOU, X. L.; WANG, G. L.; XU, Z. S.; TAN, G. F.; LI, T.; WANG, Y. H.; KHADR, A.; XIONG, A. S. Advances in research on the carrot, an important root vegetable in the Apiaceae family. Horticulture Research, v.6, n.1, p.1-15, 2019. 10.1038/s41438-019-0150-6

R CORE TEAM. R Development Core Team. R: A Language and Environment for Statistical Computing, 2020.

RODO, A. B.; MARCOS FILHO, J. Onion seed vigor in relation to plant growth and yield. Horticultura Brasileira, v.21, n.2, p.220-226, 2003.

SHARMA, H. K. Carrots Production, Processing, and Nutritional Quality. In Siddiqui, M.; Uebersax, M. A. Handbook of Vegetables and Vegetable Processing. Chichester, UK: John Wiley \& Sons, Ltd, 2018. p.589-608). 10.1002/9781119098935.ch25.

SHARMA, S.; KUMAR, R.; CHATTERJEE, S.; SHARMA, H. R. Correlation and path analysis studies for yield and its attributes in cucumber (Cucumis sativus L.). International Journal of Chemical Studies, v.6, n.2, p.2045-2048, 2018.

SILVA, P. P. D.; BARROS, A. C. S. A.; MARCOS-FILHO, J.; GOMES-JUNIOR, F. G.; NASCIMENTO, W. M. Assessment of squash seed vigor using computerized image analysis. Journal of Seed Science, v.39, n.2, p.159-165, 2017. 10.1590/2317$1545 \mathrm{v} 39 \mathrm{n} 2171177$.

SINGH, P. K.; PANDITA, V. K.; TOMAR, B. S.; SETH, R. Use of seed vigour tests to predict seedling emergence of carrot. Indian Journal of Horticulture, v.71, n.4, p.516-521. 2014.

STOLÁRIK, T.; HENSELOVÁ, M.; MARTINKA, M.; NOVÁK, O.; ZAHORANOVÁ, A.; CERNÁK, M. Effect of lowtemperature plasma on the structure of seeds, growth and metabolism of endogenous phytohormones in pea (Pisum sativum L.). Plasma Chemistry and Plasma Processing, v.35, n.4, p.659-676, 2015. 10.1007/s11090-015-9627-8.

TEKRONY, D. M.; EGLI, D. B. Relationship of Seed Vigor to Crop Yield: A Review. Crop Science, v.31, n.3, p.816-822, 1991. 10.2135/cropsci1991.0011183X003100030054x.

WANG, Y.; CUI, Y.; HU, G.; WANG, X.; CHEN, H.; SHI, Q.; XINAG, J.; ZHANG, Y.; ZHU, D.; ZHANG, Y. Reduced bioactive gibberellin content in rice seeds under low temperature leads to decreased sugar consumption and low seed germination rates. Plant Physiology and Biochemistry, v.133, p.1-10, 2018. 10.1016/j.plaphy.2018.10.020.

ZAHORANOVÁ, A.; HENSELOVÁ, M.; HUDECOVÁ, D.; KALINÁKOVÁ, B.; KOVACIK, D.; MEDVECKÁ, V.;CERNÁK, M. Effect of cold atmospheric pressure plasma on the wheat seedlings vigor and on the inactivation of microorganisms on the seeds surface. Plasma Chemistry and Plasma Processing, v.36, n.2, p.397-414, 2016. 10.1007/s11090$\underline{015-9684-z}$. 